
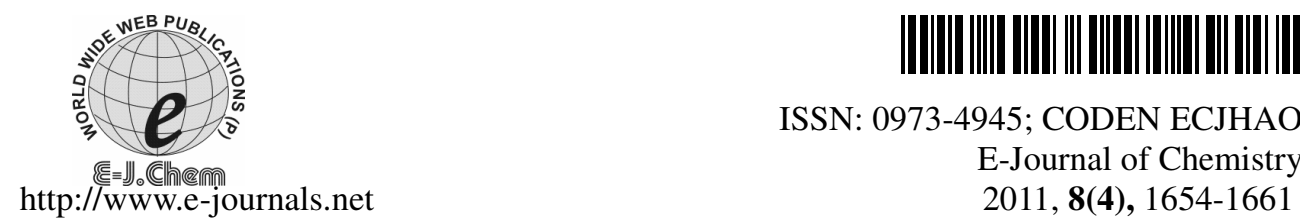

ISSN: 0973-4945; CODEN ECJHAO

E-Journal of Chemistry 2011, 8(4), 1654-1661

\title{
Ion Chromatographic Estimation of Arsenite and Arsenate at Trace Level
}

\author{
CHETAN CHAVAN*, VIJAYANAND BHATE, \\ CHANAKYA THAKER and ADITI KHANDKAR
}

Application Laboratory, Dionex(India) Pvt. Ltd., Plot R-610

TTC MIDC, Rabale, Navi Mumbai - 400710, Maharashtra, India

chetan.chavan@dionex.com

Received 6 January 2011; Accepted 1 March 2011

\begin{abstract}
Present method shows simple and specific determination of traces of inorganic arsenic in water. This method enables simultaneous determination of arsenite by electrochemical detection and arsenate by suppressed conductivity detection. The applicability of this method was illustrated by determining the inorganic arsenite and arsenate content from bore-well water and river water samples without any special pretreatment. The present method for direct determination of arsenite and arsenate shows good sensitivity, selectivity, precision and accuracy. Detection limits determined using this procedure was found to be $2.0 \mu \mathrm{g} / \mathrm{L}$ for arsenite and $30.0 \mu \mathrm{g} / \mathrm{L}$ for Arsenate. The simplicity, ease of use, low detection limit and low running cost of this method makes it appealing for increasing capability of testing in the lab.
\end{abstract}

Keywords: Arsenite, Arsenate, Ion chromatography, Conductivity, Amperometry

\section{Introduction}

Arsenic occurs naturally often together with other chemicals in soils and minerals. Arsenic and all of its compounds are poisonous in nature. Inorganic arsenic occurs as trivalent arsenite $\left(\mathrm{As}^{3+}\right)$ and pentavalent arsenate $\left(\mathrm{As}^{5+}\right)$. The toxicity of arsenic is known to depend on its chemical form. Arsenite is the most toxic of the water-soluble species; arsenate is also relatively toxic, whereas the organic methylated forms, methylarsonic acid and dimethylarsinic acid, are much less toxic ${ }^{1}$. Organic arsenic is mainly found in seafood.

The major cause of arsenic found in ground water is the oxidation of arsenopyrite or arsenic rich ferrous hydroxide present in sediments ${ }^{2}$. Bengal delta region are rich in these ores. The subsequent migration of this arsenic contaminated groundwater through these deltaic sediments may be one of the principal causes of arsenic poisoning in India and Bangladesh. Bore-well water from arsenic prone regions, water leaching from mines etc are 
also the main sources of arsenic contamination. Various Latin American countries also face the same type of problem. The possible adverse effects on human beings due to arsenicosis are dorsal keratosis, squamous cell carcinoma, gangrene, hyper keratosis, pigmentation on body. World health organization's (WHO) Guideline Value for arsenic in drinking water is $0.01 \mathrm{mg} / \mathrm{L}^{3}$. This figure is limited by the ability to analyze low concentrations of arsenic in water. A systematic study is being undertaken by the School of Environmental Studies and School of Water Resources Engg., Jadavpur University since 1989. The maximum permissible limit in India is $0.05 \mathrm{mg} / \mathrm{L}^{3}$.

In this method two detectors are used in series for the simultaneous determination of arsenite and arsenate by ion chromatography. The arsenite and arsenate are separated by separation column and eluent containing the analytes flows through electrochemical cell and then through the suppressor and finally flows through a conductivity cell.

The main aim of our present experiment was to determine the inorganic arsenic in different valence forms like $\mathrm{As}^{3+}$ and $\mathrm{As}^{5+}$ with simple analytical instrumentation like ion chromatography which almost all labs can easily handle. Hence a relatively simple and precise method was developed using ion chromatographic separation with dionex IonPac AS23 anion exchange column for the simultaneous determination of Arsenite by amperometry and arsenate by conductivity. IonPac AS23 is a high capacity column with dual selectivity of hydroxide and carbonate eluents enabling good resolution. Various ground water samples were analyzed for their arsenic content. Non-ionic impurities present in other type of samples were removed by passing through onguard II RP cartridge. Using this method one can also determine fluoride, chloride, nitrate, phosphate and sulfate on conductivity at low $\mathrm{mg} / \mathrm{L}$ level in presence of arsenite and arsenate. Resolution of the anions can be customized by changing eluent composition, if required.

\section{Experimental}

The equipment used was dionex ion chromatograph ICS 3000 with autosampler(AS) having a $200 \mu \mathrm{L}$ sample loop, IonPac AG23 guard column (4x50 mm i.d.) and IonPac AS23 separator column $(4 \times 250 \mathrm{~mm}$ i.d.) were used. The experiment was conducted using a predegassed eluent of $7.0 \mathrm{mM}$ sodium carbonate and $4.0 \mathrm{mM}$ sodium hydrogencarbonate at $1.0 \mathrm{~mL} / \mathrm{min}$ flow rate. The electrochemical detector consisted of a platinum working electrode and $\mathrm{Ag} / \mathrm{AgCl}$ as reference electrode and stainless steel body as a counter electrode. Solid electrodes are prone to complicated surface renewal problems. Oxide film formation causes non-reproducible currents during the electrolytic oxidation of arsenic solutions ${ }^{1,4}$. To overcome this problem, platinum working electrode was reconditioned before starting the analysis at a potential of $-0.80 \mathrm{~V}$ and at $+0.60 \mathrm{~V}$ for less than 30 seconds each and then the potential was reset to $+0.40 \mathrm{~V}$ and then was equilibrated for 20 minutes The suppressor used was DIonex ASRS 300 (4 mm). Software used for data acquisition was dionex chromeleon (version: 6.80 SP2). Chromatograms from both the detectors can be monitored simultaneously during analysis.

\section{Reagents}

All solutions were prepared in ultra pure water $(18.2 \mathrm{M} \Omega-\mathrm{cm})$. Unless otherwise mentioned, reagent grade chemicals were used.

Arsenic standard solution

A standard stock solution of arsenite $(1000 \mathrm{mg} / \mathrm{L})$ was prepared from arsenic trioxide $\left(\mathrm{As}_{2} \mathrm{O}_{3}\right.$,Sigma Aldrich) by weighing $0.264 \mathrm{~g}$ and dissolving in $100 \mathrm{~mL}$ of $100 \mathrm{mM}$ sodium 
hydroxide $(\mathrm{NaOH})$ (prepared from $50 \%$ w/w NaOH (sigma Aldrich)). Solution was sonnicated for 20 minutes for complete dissolution of salt. A standard stock solution of arsenate $100 \quad 0 \quad \mathrm{mg} / \mathrm{L})$ was prepared from sodium monohydrogen orthoarsenate $\left(\mathrm{Na}_{2} \mathrm{HAsO}_{4} .7 \mathrm{H}_{2} \mathrm{O}\right.$, loba chemie Ltd.) by weighing $0.416 \mathrm{~g}$ and dissolving in $100 \mathrm{~mL}$ of ultra pure water.

\section{Procedure}

An autosampler (Dionex AS) was used for the injections. Standard solution containing a mixture of arsenite and arsenate was injected into the ion chromatography system. Subsequently, the standard solution in the sample loop was transferred onto the separator column, on which arsenite and arsenate were separated. After separation on the column, the arsenite and arsenate were detected by amperometric and conductivity detectors, respectively. A sequence containing the blank, standards, samples and recovery samples was run and results were then interpreted.

Standard solutions with concentrations of arsenite of 2.0, 5.0, 10.0, 15.0, 20.0, 25.0 and $30.0 \mu \mathrm{g} / \mathrm{L}$ and arsenate ranging from 30.0, 125.0, 250.0, 375.0, 500.0, 625.0 and $700.0 \mu \mathrm{g} / \mathrm{L}$ were prepared from respective stock solution and used for calibration.

\section{Sample preparation}

Various water samples were taken for analysis. Bore-well water samples; sample 1 (Baghbazar), sample 2 (Barabazar), sample 3 (Uttarpara) were collected from Kolkata, West Bengal region. River water samples; sample 4 (Kalyan), sample 5 (Badlapur), sample 6(Karvai MIDC) and sample 7 (shelu) were collected from various areas of Ulhas River, Maharashtra. Each sample was filtered through $0.22 \mu$ nylon membrane and clear solution was used for direct injection. arsenite and arsenate concentrations were determined from the peak areas using the linearity equation of calibration curve.

\section{Results and Discussion}

This is the modified method of Tan et $a l^{4}{ }^{4}$, having advantage of better resolution and ease of use. Two individual standard solutions for arsenite and arsenate were prepared and injected separately for peak identification. One individual peak for each standard solution was observed without any interference as shown in Figure 1 and 2.

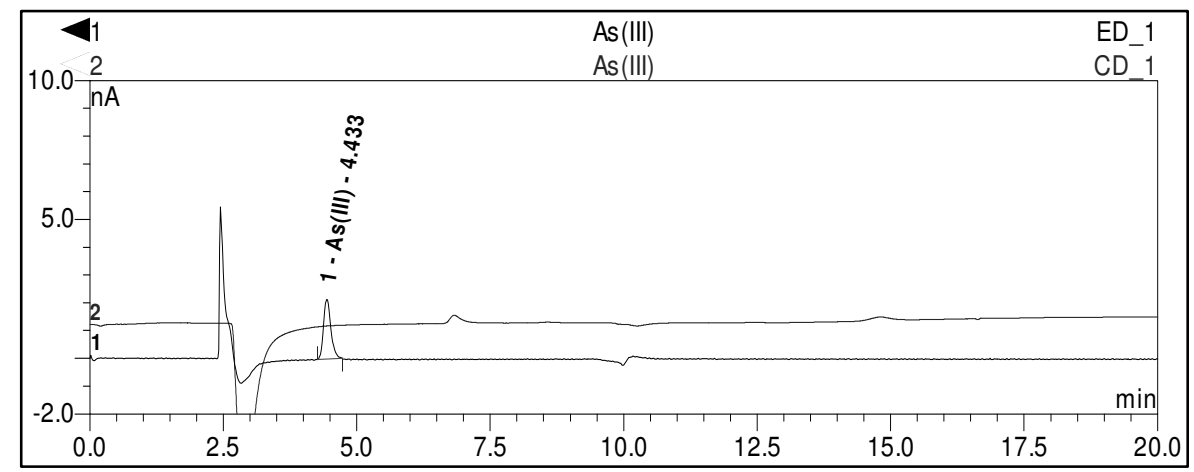

Figure 1. Amperometric detection of arsenite (Peak of arsenite was detected on amperometry channel without any interference. At the same time, no peak of arsenite and arsenate was detected on conductivity channel). 


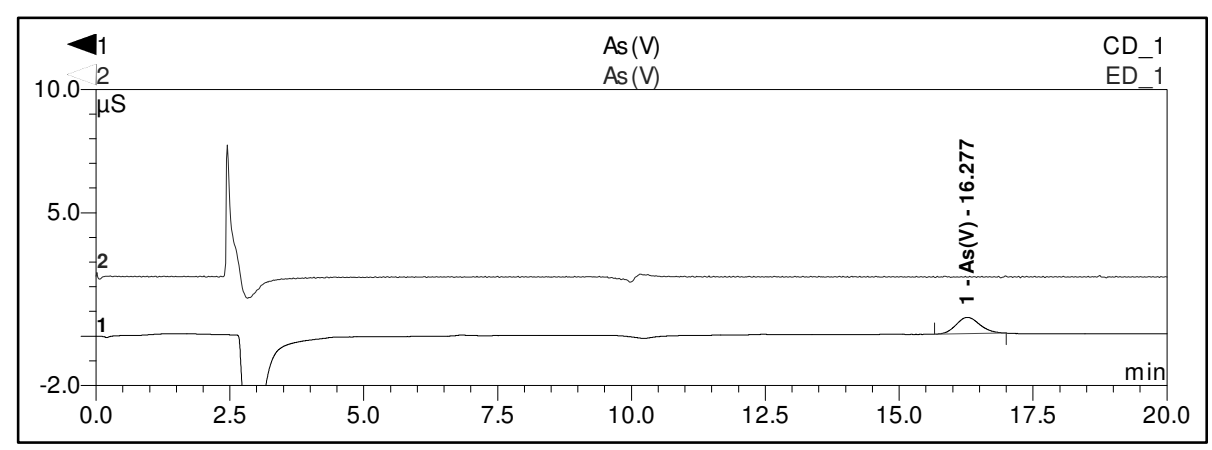

Figure 2. Conductivity detection of arsenate (Peak of arsenate was detected on conductivity channel without any Interference. At the same time, no peak of arsenite and arsenate was detected on amperometry channel).

Retention time for arsenite was 4.45 minutes and for arsenate was 16.28 minutes. The $\%$ relative standard deviation (RSD) (peak area) $(\mathrm{n}=3)$ of limit of detection (LOD) standard for arsenite $(2.0 \mu \mathrm{g} / \mathrm{L})$ was $3.27 \%$ and for arsenate $(30.0 \mu \mathrm{g} / \mathrm{L})$ was $3.49 \%$. The $\%$ relative standard deviation (RSD) (peak area) $(\mathrm{n}=6)$ of limit of quantification (LOQ) standard for arsenite $(5.0 \mu \mathrm{g} / \mathrm{L})$ was $0.91 \%$ and for arsenate $(125.0 \mu \mathrm{g} / \mathrm{L})$ was $1.40 \%$. The correlation coefficient of linearity $(n=10)$ for arsenite was 0.9992 (slope $=0.0028$, offset $=0.0006)$ and for arsenate was 0.9994 (slope $=0.0003$, offset $=-0.0092$ )
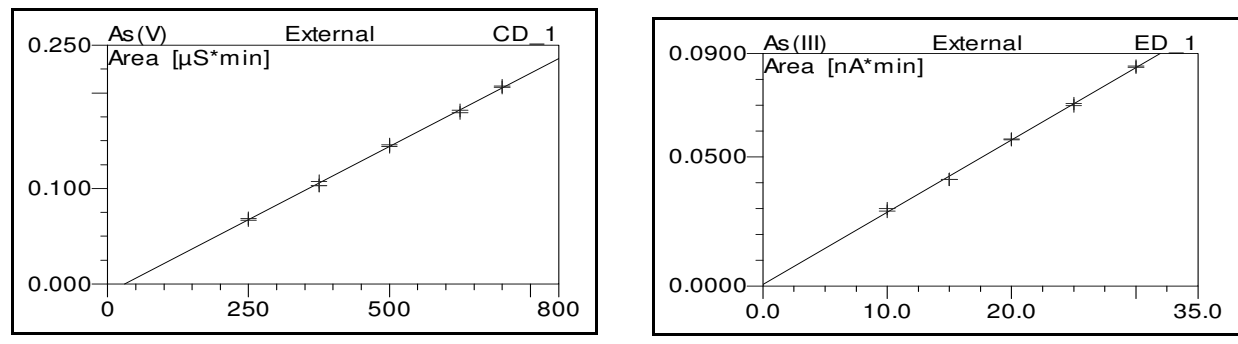

Figure 3. Linear calibration plot of arsenite and arsenate standard

A resolution mixture of chloride, nitrate, phosphate, sulfate, arsenite and arsenate was injected into the ion chromatograph system. This run shows that the method is specific for arsenite and arsenate as shown in Figure 4.

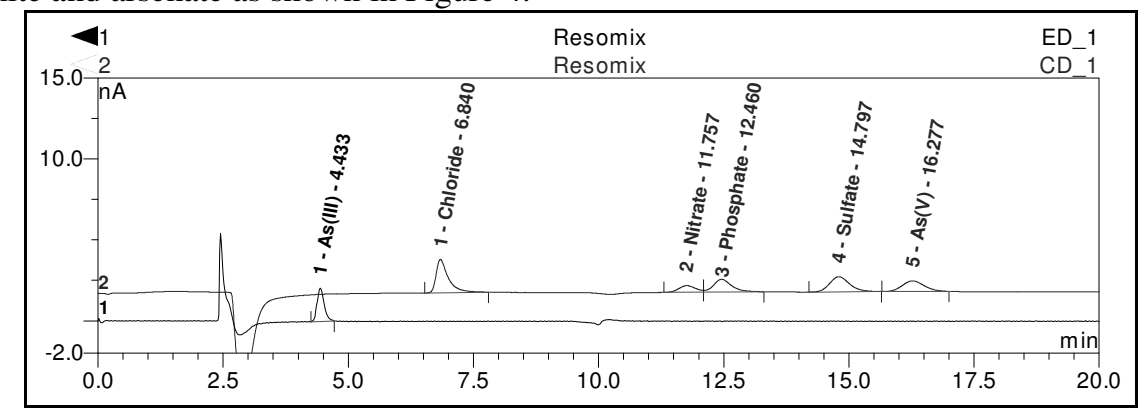

Figure 4. Specific detection of arsenite $(0.1 \mathrm{mg} / \mathrm{L})$ and arsenate $(1.0 \mathrm{mg} / \mathrm{L})$ was possible in presence of chloride $(0.5 \mathrm{mg} / \mathrm{L})$, nitrate $(1.0 \mathrm{mg} / \mathrm{L})$, phosphate $(1.0 \mathrm{mg} / \mathrm{L})$ and sulfate $(1.0 \mathrm{mg} / \mathrm{L})$ 


\section{Sample results}

Bore-well water samples (spl_1_Baghbazar, spl_2_Barabazar and spl_3_Uttarpara) and River water samples (spl_4_Kalyan, spl_Badlapur, spl_Karvai and spl_Shelu) were analysed using the linearity calibration method. Samples were injected in duplicate. The results are provided in the Table 1 after typical chromatograms of samples.

Table 1. Table shows the result obtained for arsenite and arsenate detection for various samples.

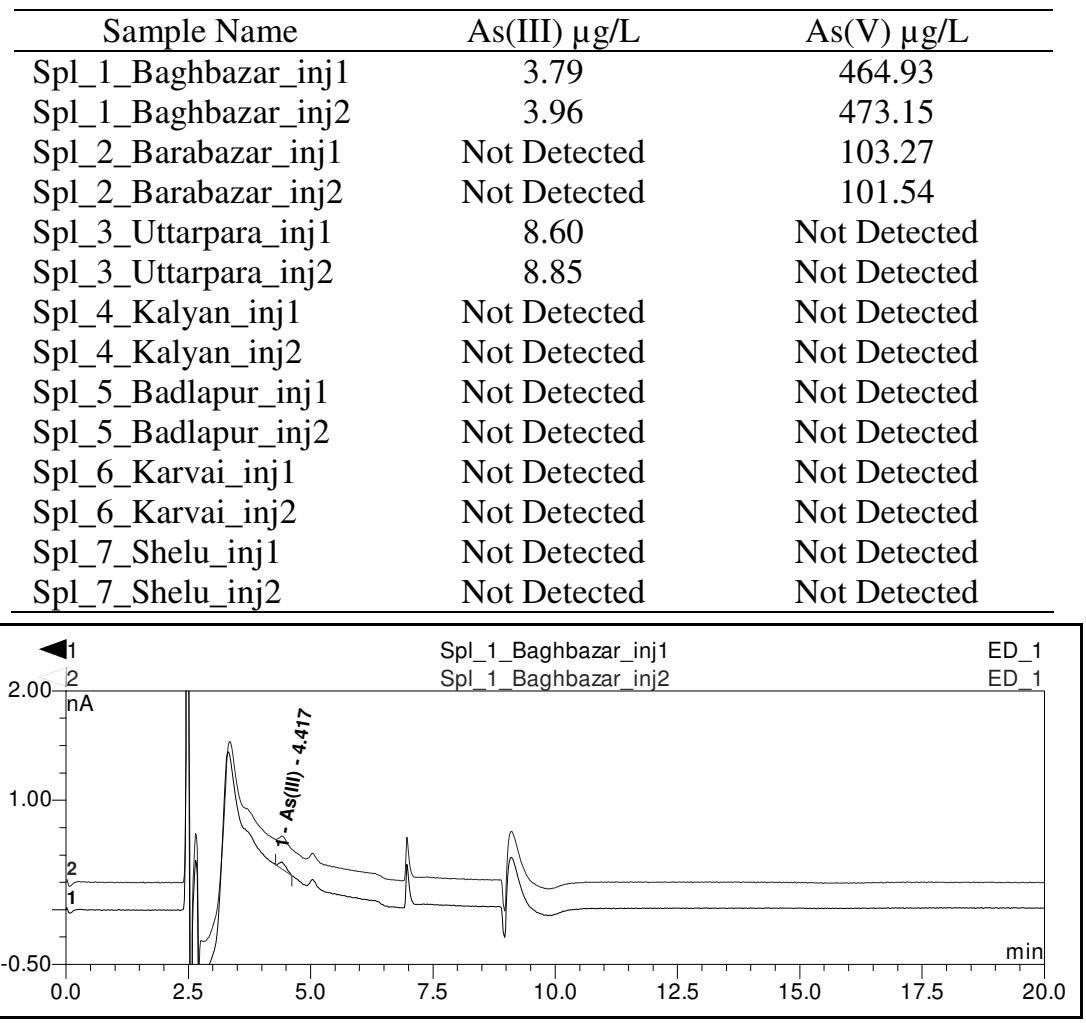

Figure 5. Electrochemical (amperometry) detection of sample_1_Baghbazar for arsenite content (duplicate injections).

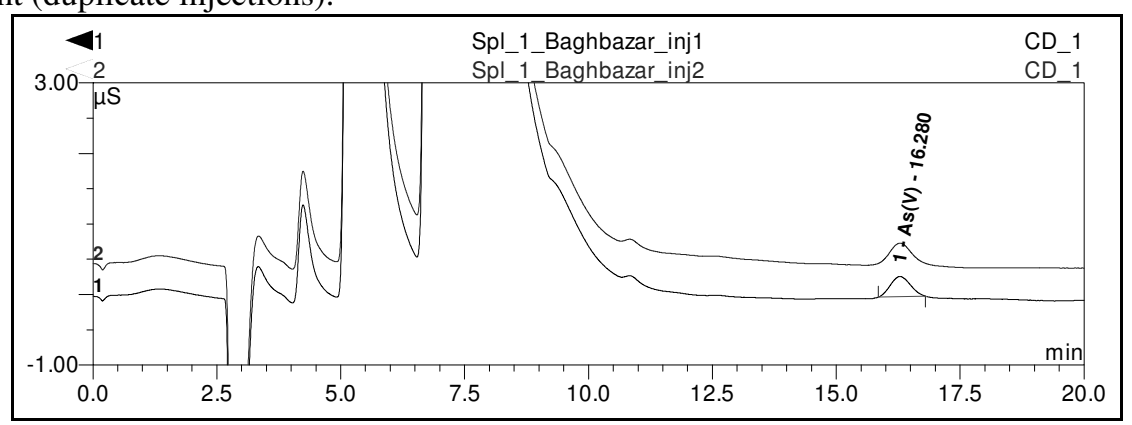

Figure 6. Conductivity detection of sample_1_Baghbazar for arsenate content (duplicate injections) 


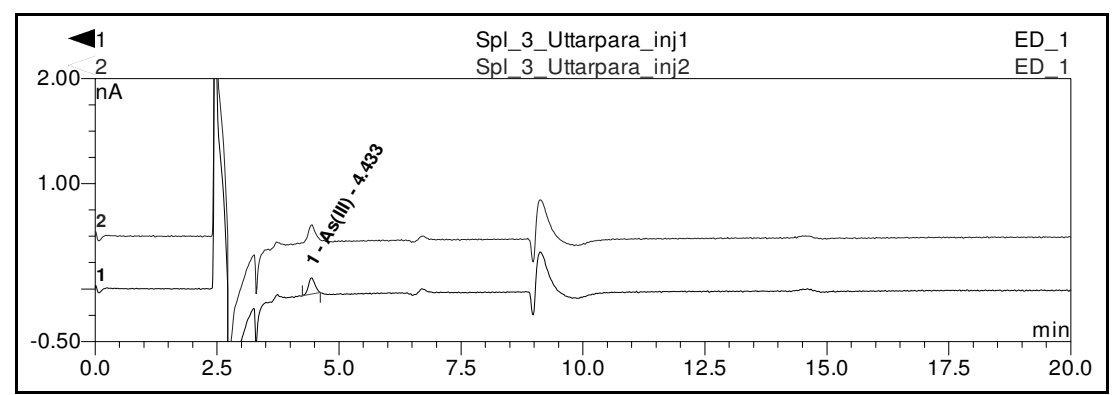

Figure 7. Electrochemical (amperometry) detection of sample_Uttarpara for arsenite content (duplicate injections)

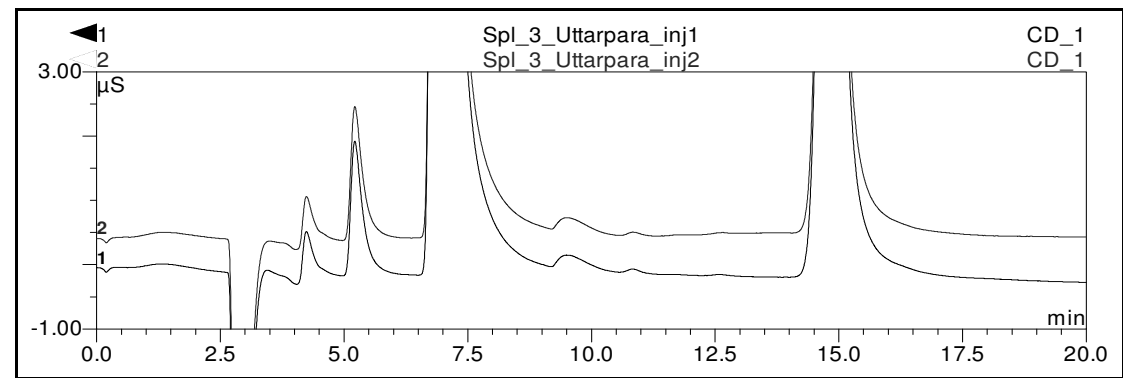

Figure 8. Conductivity detection of sample_Uttarpara for arsenate content (duplicate injections)

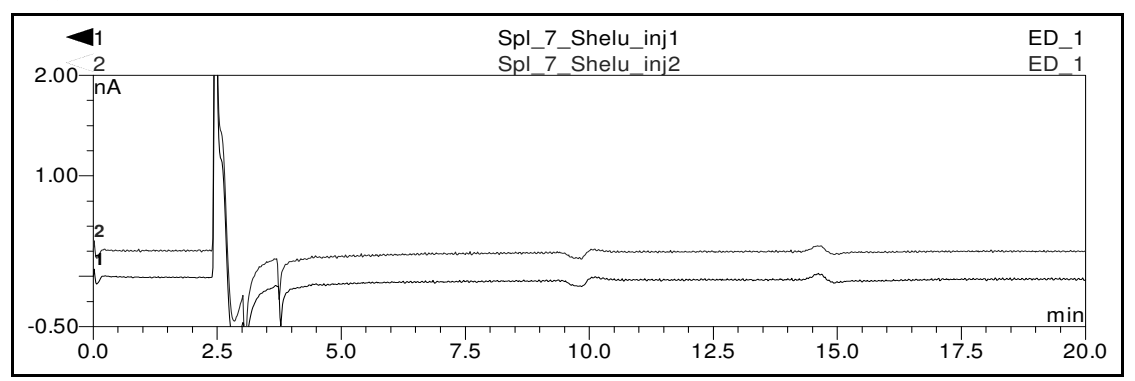

Figure 9. Electrochemical (amperometry) detection of sample_7_Shelu for arsenite content (duplicate injections)

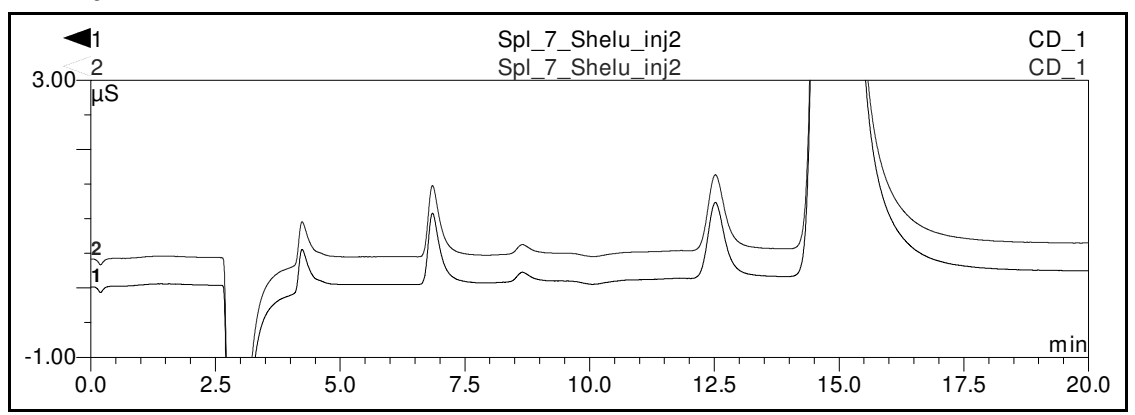

Figure 10. Conductivity detection of sample_7_Shelu for arsenate content (duplicate injections) 


\section{Recovery}

The sample used for recovery study was spl_1_Baghbazar (Average concentrations were taken for calculation). Recovery test solutions were injected in triplicate. Also for recovery study, sample was spiked with standard at three different levels as shown in Table 2 and 3.

Table 2. Table showing \% recovery and accuracy studies for arsenite determination

\begin{tabular}{|c|c|c|c|c|c|c|}
\hline \multicolumn{7}{|c|}{ Arsenite } \\
\hline 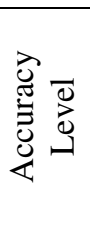 & 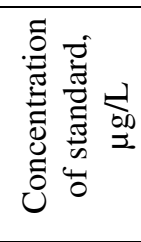 & 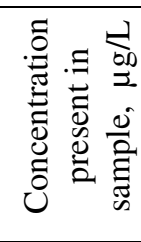 & 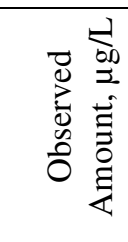 & 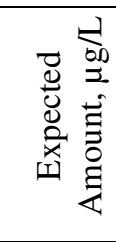 & 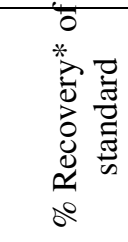 & 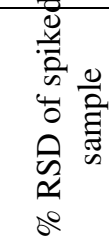 \\
\hline 1 & 15.00 & 3.90 & $\begin{array}{l}12.78 \\
12.63 \\
12.00\end{array}$ & 12.68 & $\begin{array}{l}98.34 \% \\
\pm 3.27\end{array}$ & 3.32 \\
\hline 2 & 22.50 & 3.90 & $\begin{array}{l}15.30 \\
15.26 \\
14.50\end{array}$ & 15.15 & $\begin{array}{l}99.10 \% \\
\pm 3.02\end{array}$ & 3.01 \\
\hline 3 & 45.00 & 3.90 & $\begin{array}{l}19.10 \\
19.84 \\
19.50\end{array}$ & 19.60 & $\begin{array}{c}99.39 \% \\
\pm 1.89\end{array}$ & 1.91 \\
\hline
\end{tabular}

${ }^{*}$ Each value is average of three determinations \pm standard deviation

Table 3. Table showing \% recovery and accuracy studies for Arsenate determination

\begin{tabular}{|c|c|c|c|c|c|c|}
\hline \multicolumn{7}{|c|}{ Arsenate } \\
\hline 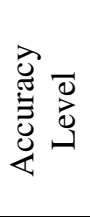 & 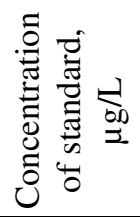 & 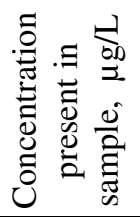 & 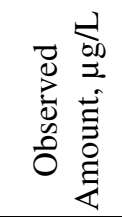 & 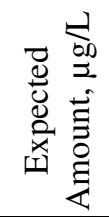 & 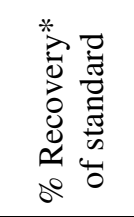 & 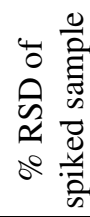 \\
\hline 1 & 375.00 & 469.00 & $\begin{array}{l}543.72 \\
544.57 \\
542.30\end{array}$ & 540.14 & $\begin{array}{c}100.63 \% \\
\pm 0.21\end{array}$ & 0.21 \\
\hline 2 & 562.50 & 469.00 & $\begin{array}{l}564.88 \\
563.35 \\
566.78\end{array}$ & 563.58 & $\begin{array}{c}100.25 \% \\
\pm 0.31\end{array}$ & 0.31 \\
\hline 3 & 1125.00 & 469.00 & $\begin{array}{l}611.62 \\
604.54 \\
609.58\end{array}$ & 605.63 & $\begin{array}{c}100.48 \% \\
\pm 0.60\end{array}$ & 0.60 \\
\hline
\end{tabular}

${ }^{*}$ Each value is average of three determinations \pm standard deviation. 


\section{Conclusion}

Amperometric electrochemical detection and suppressed conductivity detection are coupled to give specific, sensitive and precise method for simultaneous estimation of arsenite and arsenate respectively. This present method was used for analysis of water samples without any pretreament and it can be used for other type of samples with minimum pretreatment. The detection limits for arsenite was $2.0 \mu \mathrm{g} / \mathrm{L}$ and for arsenate was $30.0 \mu \mathrm{g} / \mathrm{L}$. This is significantly a low limit for arsenite, which is the most toxic in arsenic species. This technique is cost-effective with respect to analysis required for keeping a check on the limits of inorganic arsenic species in water as prescribed by the water regulatory authorities and various health organizations.

\section{References}

1. Zongli Li, Shifen Mou, Zheming Ni and John M. Riviello, Analytica Chimica Acta, 1995, 30(1), 79-87.

2. Nitinal Khummalai and Virote Boonamnuayvitaya, J Biosci Bioeng., 2005, 99(3), 277-284.

3. John Kayser, Removing Arsenic and saving lives in West Bengal, India, Water Conditioning and Purification Magazine, Oct., 2006, 48(10).

4. Tan L K and Dutrizac J E, Anal Chem., 1986, 58, 1383-1389.

5. Morita M and Edmonds J S, Pure Appl Chem., 1992, 64, 575-90.

6. Moreno E, Camara C, Corns W T, Bryce D W and Stockwell P B, J Automated Methods \& Manage in Chem., 2000, 22(2), 33-39.

7. Henry F T and Thorpe T M, Anal Chem., 1980, 52, 80-83.

8. Joachim Weiss, Handbook of Ion Chromatography, 3 Rev Upd Edition, Volume 1 \& 2, Wiley-VCH Veerlag GmbH and Co. KGaA, Weinheim, 2005, ISBN 3-527-28701-9.

9. Jackson P E, Ion Chromatography in Environmental Analysis, Meyers R. A. (Ed.), John Wiley \& Sons Ltd, Chichester, 2000, 2779-2801. 


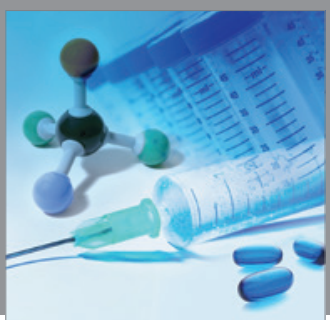

International Journal of

Medicinal Chemistry

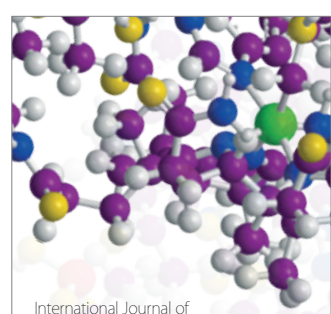

Carbohydrate Chemistry

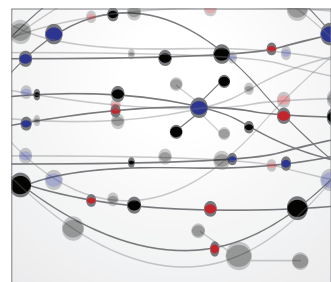

The Scientific World Journal
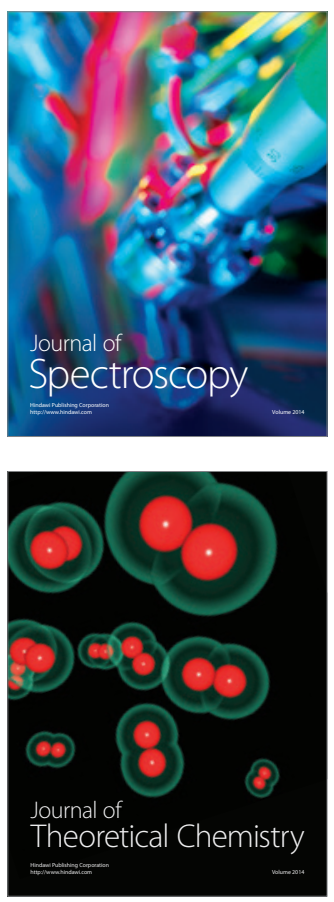
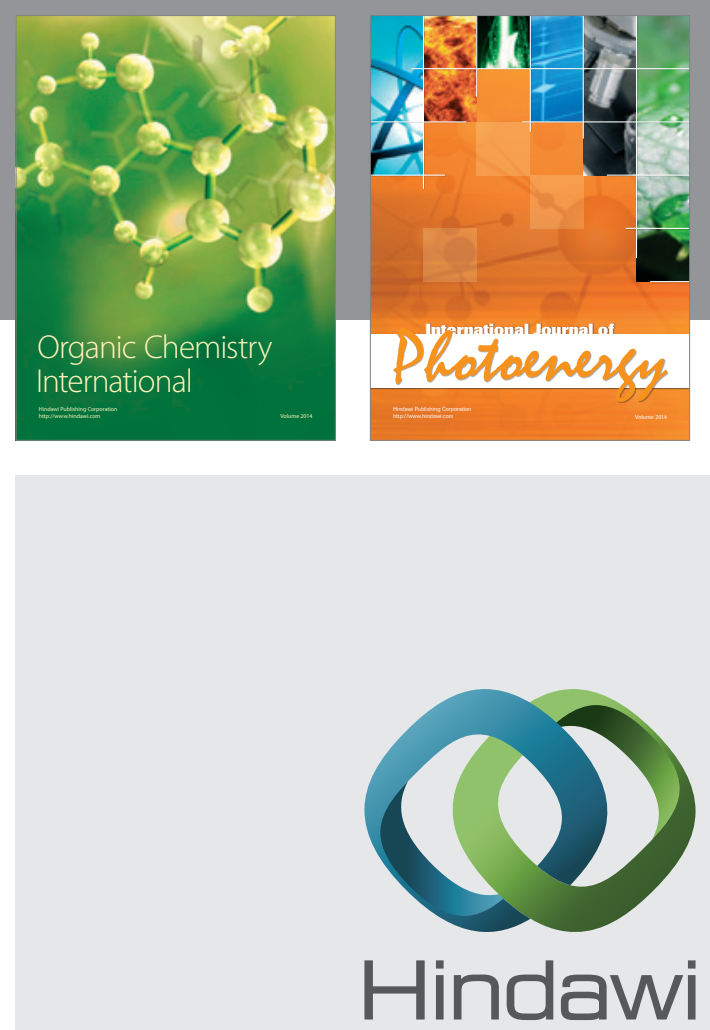

Submit your manuscripts at

http://www.hindawi.com
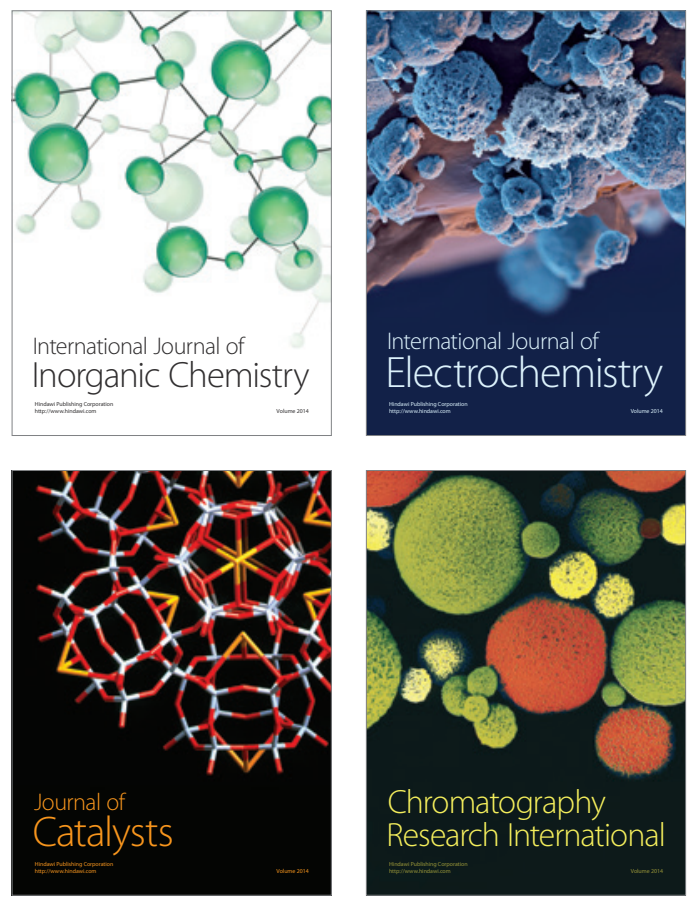
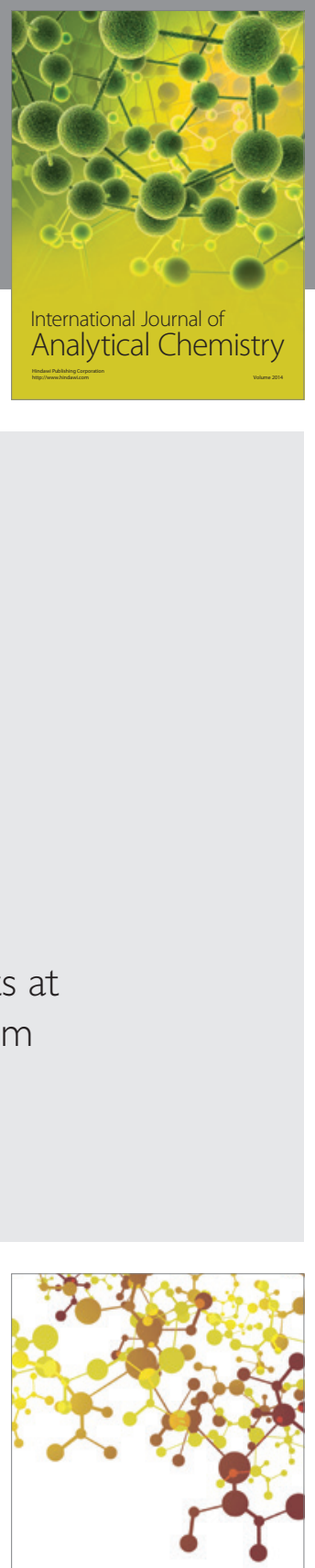

Journal of

Applied Chemistry
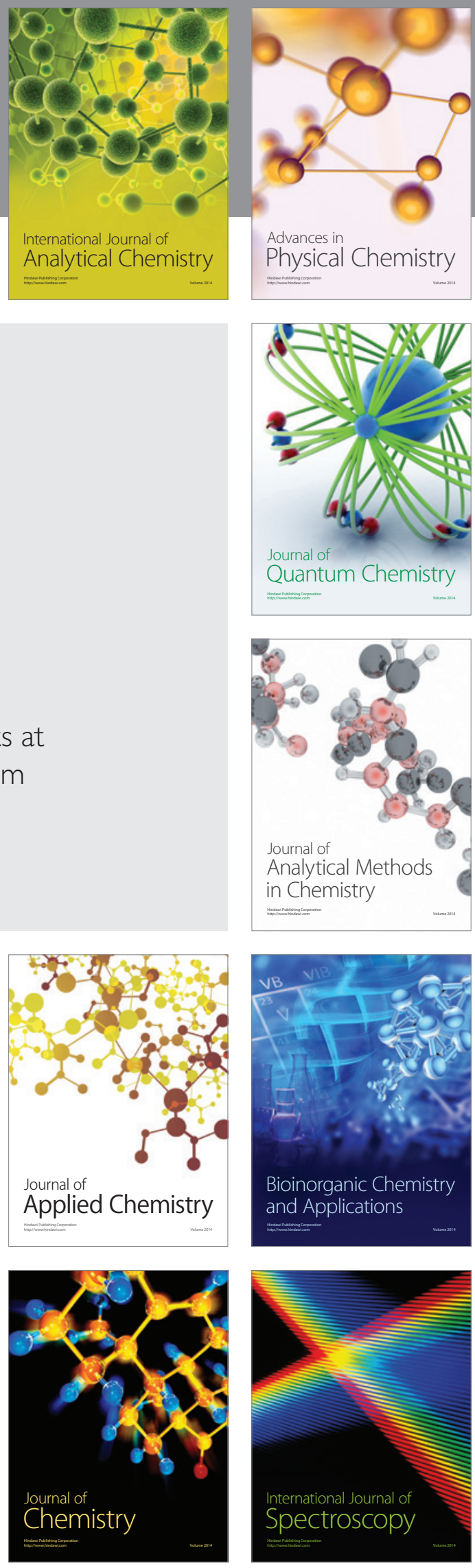